\title{
Model Example Non Example Dalam Pembelajaran Tajwid
}

\author{
Partono \\ partono@iainkudus.ac.id \\ Institut Agama Islam Negeri (IAIN) Kudus \\ Hamengkubuwono \\ hamengku@gmail.com \\ Institut Agama Islam Negeri (IAIN) Curup \\ Jeni Fransiska \\ jenyfransiska@gmail.com \\ Institut Agama Islam Negeri (IAIN) Curup
}

\begin{abstract}
The problem that often occurs to teachers when teaching is that many students are less eager to learn. Therefore, it is necessary to have a new innovation from a teacher to overcome this, namely by using the example non-example model, which is a learning model that uses an image display to be analyzed, where the learning model is aimed at student activeness that allows the teacher to stimulate student enthusiasm by making their vital organs move and focus on tajwid learning in the TPQ Hikmatun Najah Blora so that students can be more active because they themselves will play a role in analyzing the image of verse fragments. This study is included in the category of descriptive qualitative research with the data obtained sourced from primary data sources, namely research main data obtained directly from research data sources namely respondents by interview, observation and documentation. The results of this study indicate that the use of the example nonexample model in Tajweed learning at TPQ Hikmatun Najah Blora adds more effectiveness because it can affect student learning outcomes because students become active because it raises the student's thinking and critical thinking so that it raises a high curiosity towards the material delivered.
\end{abstract}

Keywords: Learning Model; Example Non-Example; Learners; Liveliness; Tajweed. 
24 | Belajea: Jurnal Pendidikan Islam, Vol. 5, No. 01, 2020

\begin{abstract}
Abstrak: Masalah yang sering terjadi kepada guru ketika mengajar adalah banyaknya siswa yang kurang bersemangat untuk belajar. Maka dari itu perlu adanya sebuah inovasi baru dari seorang guru untuk mengatasi hal tersebut, yakni dengan menggunakan model example non-example yakni sebuah model pembelajaran yang menggunakan tampilan gambar untuk dianalisis, dimana model pembelajaran ini tertuju kepada keaktifan siswa yang memungkinkan guru dapat memacu semangat siswa dengan membuat organ vital mereka bergerak dan terpusat pada pembelajaran tajwid di TPQ Hikmatun Najah Blora sehingga siswa dapat lebih aktif karena mereka sendiri yang akan berperan dalam menganalisis gambar potongan ayat. Penelitian ini termasuk dalam kategori penelitian diskriptif kualitatif dengan data yang diperoleh bersumber pada sumber data primer, yaitu data pokok penelitian yang diperoleh langsung dari sumber data penelitian yaitu responden dengan cara wawancara, observasi dan dokumentasi. Hasil penelitian ini menunjukan bahwa dengan penggunaan model example non-example dalam pembelajaran Tajwid di TPQ Hikmatun Najah Blora menambah semakin efektif dikarenakan dapat mempengaruhi hasil belajar siswa karena siswa menjadi aktif karena memunculkan ghirah serta kekritisan berfikir para peserta didik sehingga memunculkan rasa keingintahuan yang tinggi terhadap materi yang disampaikan.
\end{abstract}

Kata Kunci: Model Example, Non Example, Pembelajaran Tajwid

\title{
Pendahuluan
}

Merujuk pada UU No 20 Tahun 2003, dan PP No 19 Tahun 2005 tentang Standart Nasional Pendidikan Pasal 19 Standart proses dinyatakan bahwa proses pembelajaran satuan pendidikan diselenggarakan secara inspiratif, interaktif, menantang, menyenangkan, memotivasi peserta didik untuk berpartisipasi secara aktif, serta memberikan ruang yang cukup bagi prakarsa, kreativitas dan kemandirian sesuai dengan bakat, minat, dan perkembangan fisik serta psikologi peserta didik. Maka dari itu kualitas pembelajaran dikelas diharapkan siswa selalu aktif dalam proses pembelajaran di kelas sehingga tercipta suasana belajar yang efektif dan efisien.

Namun kita ketahui bahwa kualitas pendidikan kita dianggap oleh sebagian kalangan masih rendah yang disebabkan mulai dari banyaknya faktor, 
mulai dari rendahnya kualitas guru, sampai sarana dan prasarana yang tidak lengkap. Kualitas pendidikan juga dipengaruhi oleh ketidakmampuan guru dalam menerapkan dan menggunakan pendekatan yang sesuai dengan mata pelajaran yang akan diajarkan, sehingga apa yang menjadi indikator yang ingin dicapai dalam proses pembelajaran tidak maksimal tercapai dan diserap oleh siswa ${ }^{1}$.

Rendahnya kualitas pendidikan di Indonesia tersebut, karena dalam sistem pendidikan nasional di Indonesia ada masalah. Kesalahan pertama berupa paradigma pendidikan yang menjadi dasar seluruh penyelenggaraan sistem pendidikan. Berikutnya adalah masalah model pembinaan guru dan strategi pembelajaran, masalah penyelenggaraan pendidikan berupa biaya mahal, saranaprasarana kurang dan kesejahteraan guru relatif rendah. Data tentang rendahnya kualitas pendidikan di Indonesia, ditunjukkan Prof. Tjipto dalam hasil penelitian, yang menyebutkan dari 146.052 SD di Indonesia hanya ada 8 SD yang mendapat pengakuan dunia dalam kategori The Primary Years Program (PYP). Di jenjang SMP, dari 20.918 sekolah di Indonesia yang diteliti, hanya ada 8 SMP yang mendapat pengakuan dunia dalam kategori The Middle Years Program (MYP). Sedangkan di jenjang SMA, ari 8.036 sekolah yang diteliti hanya ada 7 SMA yang mendapat pengakuan dunia dalam kategori The Diploma Program. ${ }^{2}$

Berlatar belakang penjelasan diatas, maka dapat diketahui bahwa perlu adanya inovasi pembelajaran yang perlu dilakukan oleh pendidik untuk mengatasi hal tersebut. Salah satunya adalah dengan menggunakan model pembelajaran yang tepat dan efektif yang dapat memfasilitasi peserta didik untuk dapat berkembang sendiri sesuai dengan kemauannya sendiri tanpa adanya paksaan dari pendidik atau guru. Salah satunya adalah dengan menggunakan model pembelajaran Example non-Example. Penggunaan model pembelajaran ini diharapkan mampu mengatasi permasalahan peserta didik sehingga dapat mengatasi permasalahan yang ada sehingga dapat memicu peserta didik untuk bisa lebih aktif dalam pembelajaran dengan indikator bekerjanya semua organ vital peserta didik yang dapat digunakan untuk memahami materi yang disampaikan oleh pendidik.

${ }^{1}$ Agung Rimba Kurniawan and Diya Ul'hak, "Cara Guru Meningkatkan Keaktifan Siswa SD,” PGSD FKIP Universitas Jambi., 2017, 12.

${ }^{2}$ Tjipto Subadi, "Model Pembinaan Guru Ilmu Sosial Berbasis Lesson Study Menuju Pendidik Profesional" (Surakarta, 2018). 20. 
Taman Pendidikan Al Qur'an (TPQ) Hikkmatun Najah Blora sebagai salah satu bentuk lembaga pendidikan non formal yang membidangi pengajaran baca tulis Al Qur'an selama ini dianggap sebagai lembaga yang kurang bisa mengikuti perkembangan dalam inovasi pembelajaran bagi siswanya. Hal ini mungkin disebabkan kurangnya perhatian dari pemerintah baik pusat maupun daerah. Pembelajaran tajwid sebagai salah satu materi yang diajarkan di TPQ Hikmatun Najah Blora selama ini oleh para pendidik menurut penulis kurang dapat menarik perhatian atau fokus peserta didik pada saat prosesi belajar mengajar. Hal itu dikarenakan banyaknya pendidik yang kurang inovatif ketika mengajar, karena kebanyakan mengunakan metode ceramah dimana pembelajaran hanya terfokus kepada pendidik saja, dan peserta didik di paksa untuk menghadapi kebosanan itu. Maka dengan model pembelajaran yang inovatif berupa example non-example akan meredupsi problematika yang seperti itu, akan tetapi disini diperlukan keprofessionalan dan kekreatifan pendidik untuk dapat mewujudkan peseerta didik yang aktif dalam pembelajaran.

Menurut penulis, penerapan model pembelajaran example non-example tidaklah terlalu sulit dan tidak terlalu memakan biaya yang banyak, hanya cukup dengan strategi dan beberapa media pendukung agar dapat tercapainya tujuan pembelajaran yang akan disampaikan, yakni pembelajaran tajwid. Maksud dan tujuan penelitian disini adalah agar para pendidik dapat mengetahui apa pengertian dari model pembelajaran example non-example, untuk mengetahui bagaimana prinsip prinsip dalam model pembelajaran example non-example, untuk mengetahui apa kelebihan dan kekurangan dari model pemelajaran example nonexample dan terahir untuk mengetahui langkah langkah model pembelajaran example non-example.

Penelitian ini termasuk dalam jenis penelitian lapangan (field research), yaitu sebuah studi penelitian yang mengambil data autentik secara obyektif/studi lapangan. Peneliti melakukan studi langsung ke lapangan untuk memperoleh data yang konkret tentang implementasi metode example non example di TPQ Hikmatun Najah Blora. Penelitian ini termasuk penelitian diskriptif kualitatif. Penelitian deskriptif kualitatif adalah penelitian yang dilakukan untuk mengetahui nilai variabel mandiri, baik satu variabel atau lebih tanpa membuat perbandingan, atau menghubungan dengan variabel yang lain ${ }^{3}$. Adapun data

${ }^{3}$ Kris H Timotius, Pengantar Metodologi Penelitian: Pendekatan Manajemen Pengetahuan Untuk Perkembangan Pengetahuan, CV. Andi Offset (Yogyakarta, 2017), 28. 
yang diperoleh pada penelitian ini bersumber pada sumber data primer, yaitu data pokok penelitian yang diperoleh langsung dari sumber data penelitian yaitu responden dengan cara wawancara, observasi dan dokumentasi. Sementara untuk sumber data sekunder, yaitu sumber data-data pendukung/pelengkap penelitian ini diperoleh dari buku/jurnal/arikel/ tulisan dari berbagai data yang mendukung dan berkaitan dengan penelitian ${ }^{4}$.

\section{Pembahasan}

\section{Metode Pembelajaran Example Non Example}

Salah satu ciri masyarakat modern adalah selalu ingin ada perubahan yang menjurus ke hal yang lebih baik. Hal ini tentu saja menyangkut berbagai bidang, termasuk bidang pendidikan. Komponen yang melekat pada pendidikan diantaranya adalah kurikulum, guru dan siswa. Dalam proses pembelajaran peran guru sangatlah memiliki posisi sentral karena guru yang menentukan ketercapaian tujuan pembelajaran.

Tuntutan perubahan paradigma dalam pembelajaran ditegaskan dalam beberapa aturan antara lain. 1. Undang-undang Sistem Pendidikan Nasional No 20 Tahun 2003 pasal 4 ayat 4 menegaskan bahwa pendidikan diselenggarakan dengan memberi keteladanan, membangun kemauan, dan mengembangkan kreativitas siswa dalam proses pembelajaran 2. Pendidikan diselenggarakan sebagai proses pembudayaan dan pemberdayaan siswa yang berlangsung sepanjang hidup, dan 3. Proses pembelajaran dalam satuan pendidikan diselenggarakan secara interaktif, inspiratif, menyenangkan, menantang, motivasi siswa untuk aktif, serta memberikan ruang yang cukup bagip rakarsa, kreativitas, dan kemandiriansesuai dengan minat, bakat, dan perkembangan fisik dan psikologis siswa ${ }^{5}$.

Dengan berpijak pada aturan-aturan di atas, maka pembelajaran yang dilaksanakan di sekolah harus memfasilitasi peningkatan mutu pendidikan yang dalam hal ini dijabarkanningkatan mutu pembelajaran pada setiap mata pelajaran, yakni dengan menggunakan model pembelajaran yang menarik, siswa aktif, dan inovatif.

\footnotetext{
${ }^{4}$ Albi Anggito and Johan Setiawan, Metodologi Penelitian Kualitatif (Sukabumi, 2018).32. 2016), 10.

${ }^{5}$ Nurdyansyah and Eni Fariyatul Fahyuni, Inovasi Model Pembelajaran (Sidoarjo,
} 
Dalam Peraturan Menteri Pendidikan Nasional Nomor 41 Tahun 2007 mengenai Standar Proses untuk Satuan Pendidikan Dasar dan Menengah, diuraikan bahwa: "pembelajaran adalah proses interaksi peserta didik dengan guru dan sumber belajar pada suatu lingkungan belajar. Proses pembelajaran perlu direncanakan, dilaksanakan, dinilai, dan diawasi. Pelaksanaan pembelajaran merupakan implementasi dari RPP. Pelaksanaan pembelajaran meliputi pendahuluan, inti dan terahir yakni kegiatan penutup.

Menurut Trianto yang dikutip oleh Affandi dkk, konsep dari model pembelajaran disebutkan bahwa model pembelajaran yakni suatu perencanaan sebagai pedoman saat merencanakan pembelajaran di kelas atau dalam pembelajaran tutorial. Model pembelajaran Example non-Example ini mengacu kepada pendekatan pembelajaran yang akan digunakan, termasuk di dalamnya tujuan pengajaran, tahapan dalam kegiatan pembelajaran, lingkungan pembelajaran, juga pengelolaan kelas. Jadi dapat didefinisikan bahwa model pembelajaran berarti prosedur atau pola yang sistematis yang digunakan sebagai pedoman untuk mencapai tujuan pembelajaran ${ }^{6}$.

Mengajar merupakan proses membuat hasil belajar dapat tercapai. Hal ini selanjutnya secara kontekstual diterjemahkan sebagai beragam upaya yang dilakukan oleh guru dalam memudahkan suatu pembelajaran untuk difahami oleh siswa. Untuk itulah beragam alat dan bahan digunakan oleh guru untuk mencapai hal tersebut. Sebab pembelajaran tentu tidak akan bermakna disaat tidak memiliki dampak yang berarti terhadap siswa sebagai peserta didik.

Meski dengan semua karakteristik mata pelajaran yang harus disampaikan oleh guru, tentunya penguasaan materi yang dimiliki telah cukup memberikan modal yang cukup besar untuk guru dapat membahasakan materi pembelajaran itu dalam bahasa siswa. Untuk itulah maka guru perlu menyusun langkah-langkah sistematis untuk melaksanakan pembelajaran. Dengan tahapan langkah yang sistematis, seorang guru berharap pembelajaran dapat berlaku sebagaimana dia inginkan dan siswa dengan mudah memahami materi pembelajaran betapa pun tingkat kesulitannya. Dalam hal ini terlihat betapa peran guru menjadi sangat penting untuk menjadikan pembelajaran menjadi hal 2013), 15.

${ }^{6}$ Muhamad Afandi, Model Dan Metode Pembelajaran Di Sekolah (Semarang, 
menyenangkan. Sebab relasi hubungan antara siswa, guru dan ruang kelas adalah hubungan ${ }^{7}$.

Nampak jelas betapa pentingnya keterkaitan antara pendidik dengan model pembelajaran yang akan digunakan. Selain menciptakan model pembelajaran yang tepat dalam proses pembelajaran di kelas, guru pun dapat menjadi pelaksana dari model yang telah dipilihnya. Untuk bisa menerapkan model pembelajaran guru tentunya perlu memiliki pengetahuan tentang karakteristik setiap model yang ada. Tanpa hal itu tentu model pembelajaran tidak akan berarti apa-apa. Guru pun juga perlu menyesuaikan kondisi siswa, sekolah, lingkungan, keterbatasan alat dan bahan yang dimiliki dan hal-hal yang dianggap penting lainnya.

Metode pembelajaran example non example adalah metode pembelajaran yang menggunakan contoh contoh, yang dapat diperoleh dari kasus atau gambar yang relevan dengan Kompetensi Dasar. Menurut Miftahul Huda yang dikutip oleh Fendi dan Arif metode example non example merupakan strategi pembelajaran yang menggunakan gambar sebagai media untuk menyampaikan materi pelajaran ${ }^{8}$. Menurut Buebl(1996) dalam Apariani menjelaskan bahwa examples non examples adalah taktik yang dapat digunakan untuk mengajarkan definisi konsep. Taktik ini bertujuan untuk mempersiapkan siswa secara cepat dengan menggunakan 2 hal yang terdiri dari examples dan non examples dari suatu definisi konsep yang ada dan meminta siswa untuk mengklasifikasikan keduanya sesuai dengan konsep yang ada. Examples memberikan gambaran akan sesuatu yang menjadi contoh akan suatu materi yang sedang dibahas, sedangkan non examples memberikan gambaran akan sesuatu yang bukanlah contoh dari suatu materi yang sedang dibahas. ${ }^{9}$

Model example non-example merupakan salah satu dari pendekatan group investigation dalam pembelajaran kooperatif yang merupakan suatu alternatif terhadap model pembelajaran kelas tradisional dan menghendaki peserta didik

${ }^{7}$ Ninik Sri Widayati and Hafis Muaddab, Model-Model Pembelajaran Inovatif, El Haf Publishing (Jombang, 2012), 18.

${ }^{8}$ AB Johan and Fendi Lestiawan, "Penerapan Metode Pembelajaran Example Non Example Untuk Meningkatkan Keaktifan Dan Hasil Belajar Dasar-Dasar Pemesinan," Taman Vokasi, 2018. 34.

9 Apriani, "Implementasi Model Pembelajaran Example Non Example" (IKIP PGRI, 2010). 40. 
untuk saling membantu dalam kelompok kecil dan lebih dicirikan oleh penghargaan kooperatif daripada individu. Salah satu media dalam proses belajar mengajar adalah menggunakan media gambar. Media gambar adalah salah satu alat yang digunakan dalam proses belajar mengajar yang dapat membantu mendorong siswa lebih melatih diri dalam mengembangkan pola pikirnya. Dengan menerapkan media gambar diharapkan dalam pembelajaran dapat bermanfaat secara fungsional bagi semua siswa. Sehingga diharapkan dalam kegiatan pembelajaran akan termotivasi untuk belajar. Sebuah gambar mempunyai peranan penting dalam proses pembelajaran, yaitu untuk mempermudah imajinasi siswa ketika belajar. Selain itu juga siswa dapat melatih mencari dan memilih urutan yang logis sesuai dengan materi yang dipaparkan guru. Dengan demikian dalam Model Pembelajaran example non-example tercakup teori belajar konstruktivisme ${ }^{10}$.

Penekanan dalam model Pembelajaran example non-example ini ada pada konteks analisa peserta didik dan lebih dominan digunakan di kelas tingkat tinggi, namun dapat juga digunakan di kelas tingkat rendah dengan menenkankan aspek psikologis dan tingkat perkembangan peserta didik seperti; kemampuan berbahasa, menulis, lisan, kemampuan analisis yang notabene ringan, dan kemampuan berinteraksi dengan peserta didik lainnya.

Model pemebelajaran memiliki dampak instruksional dan dampak pengiring. Dampak instruksional adalah dampak yang terlihat setelah kegiatan pembelajaran. Sedangkan dampak pengiring adalah dampak yang tidak langsung terlihat, akan tetapi mengiringi dampak instruksional. Dampak instruksionalnya adalah siswa menjadi lebih aktif juga berani berpendapat, aktif berdiskusi, dapat belajar dari pengamatannya sendiri. Dampak pengiringnya adalah siswa dapat meningkatkan kerjasama untuk materi yang ditugaskan, berjiwa tanggung jawab, berusaha memahami materi secara intens, dan meningkatkan kemampuan problem solving siswa ${ }^{11}$.

${ }^{10}$ Selvia Rosalina, "Penerapan Model Pembelajaran Example Non Example Untuk Meningkatkan Motivasi Dan Hasil Belajar Siswa Pada Mata Pelajaran PKn Kelas VIII B Di SMP Negeri 1 Kejayan Kabupaten Pasuruan,” http://library.um.ac.id, 2014, 43.

${ }^{11}$ Syarifah Habibah, "Penggunaan Model Pembelajaran Examples Non Examples Terhadap Ketuntasan Hasil Belajar Siswa Pada Materi Tokoh-Tokoh Pergerakan Nasional Kelas V SDN 70 Banda Aceh,” Pesona Dasar 3 (2016), 45. 
Menurut Istarani yang dikutip oleh Syarifah Habibah, mengemukakan kelebihan dari model example non-example antara lain:

a. Pembelajaran lebih menarik, sebab gambar dapat meningkatkan perhatian anak untuk mengikuti proses belajar mengajar.

b. Siswa lebih cepat menangkap materi ajar karena guru menunjukkan gambar-gambar dari materi yang ada.

c. Dapat meningkatkan daya nalar atau pikir siswa sebab ia disuruh guru untuk menganalisis gambar yang ada.

d. Dapat meningkatkan kerja sama antara siswa sebab siswa diberikan kesempatan untuk berdiskusi dalam menganalisis gambar yang ada.

e. Pembelajaran lebih berkesan sebab siswa dapat secara langsung mengamati gambar yang telah dipersiapkan oleh guru.

Sedangkan kekurangannya adalah sebagai berikut

a. Kelas menjadi gaduh

b. Membutuhkan waktu yang lama ${ }^{12}$.

Langkah langkah utama dalam penggunaan model pembelajaraan ini adalah sebagai berikut:

a. Guru mempersiapkan dahulu gambar gambar sesuai dengan tujuan pembelajaran

b. Guru menempelkan gambar di papan atau di tayangkan melalui proyektor LCD

c. Guru memberi petunjuk dan memberi kesempatan pada peserta didik untuk memperhatikan atau menganalisa gambar

d. Melalui diskusi beberapa kelompok peserta didik, hasil diskusi dari analisa gambar tersebut dicatat pada kertas

e. Tiap kelompok berkesempatan membacakan hasil diskusinya

f. Dari komentar atau hasil diskusi peserta didik, guru mulai menjelaskan materi sesuai tujuan yang sudah direncanakan

g. Guru menyimpulkan ${ }^{13}$.

${ }^{12}$ Habibah. "Penggunaan Model Pembelajaran Examples Non Examples Terhadap Ketuntasan Hasil Belajar Siswa Pada Materi Tokoh-Tokoh Pergerakan Nasional Kelas V SDN 70 Banda Aceh.” Pesona Dasar 3 (2016) .25.

${ }^{13}$ Darmadi, Pengembangan Model Dan Metode Pembelajaran Dalam Dinamika Belajar Siswa (Yogyakarta: CV.Budi Utama, 2017), 19. 
Langkah langkah yang dapat diterapkan oleh guru pada materi Tajwid adalah sebagai berikut:

a. Guru menyampaikan tujuan pembelajaran (Bab Tajwid)

b. Guru memberikan pengarahan tentang sistematika pembagian kelompok (membagi beberapa kelompok)

c. Guru memberikan petunjuk tentang pelaksanaan model pembelajaran example non-example

d. Guru menampilkan gambar tulisan yang berisi beberapa potongan ayat Qur'an yang mempunyai bacaan tajwid (terdapat beberapa gambar yang berbeda, dan jumlah tergantung kelompok yang ada)

e. Guru memberikan instruksi (menyuruh siswa untuk menuliskan temuan kata per ayat untuk di analisis bacaan Tajwidnya sebanyak mungkin) dan membatasi waktu (menyesuaikan)

f. Guru berkeliling dan mengamati cara kerja kelompok sembari menilai individu untuk bahan evaluasi

g. Guru meminta kepada setiap kelompok untuk mempresentasikan hasil analisa gambar ayat yang telah didiskusikan

h. Semua kelompok memperhatikan kelompok yang presentasi

i. Guru mengambil kertas hasil dari analisa kelompok

j. Guru menjelaskan materi sesuai dengan hasil yang telah didiskusikan oleh setiap kelompok

k. Guru memberikan penghargaan untuk kelompok yang paling tepat

1. Guru bersama peserta didik menyimpulkan pelajaran secara bersama sama

m. Guru mengevaluasi dari awal sampai akhir ${ }^{14}$.

Kegiatan pendidikan menurut pendapat dari Paulo Freire yang dikutip oleh Arif Rohman merupakan kegiatan memahami makna atas realitas yang dipelajari. Kegiatan tersebut menuntut sikap kritis (critical attitude) dari para pelaku yaitu peserta didik dan pendidik. Dengan bantuan pembimbingan dan pendampingan oleh pendidik, peserta didik dituntut secara aktif dan kreatif memahami makna dari realitas dunia untuk kebaikannya ${ }^{15}$. Pengertian dari

${ }^{14}$ Nur Asmah Djafar, "Penerapan Model Pembelajaran Example Non Example Untuk Meningkatkan Kemapuan Berfikir Kritis Peserta Didik Kelas VIII.K SMP Negeri 4 Sungguminasa Kabupaten Gowa,” Kajian Dan Penelitian Biologi, 2014.25.

15 Arif Rahman, Memahami Pendidikan Dan Ilmu Pendidikan (Yogyakarta: Leksbang Mediatama, 2008), 35. 
belajar adalah suatu perubahan tingkah laku pada individu individu yang belajar yang tidak hanya berkaitan dengan penambahan ilmu pengetahuan saja, namun juga kecakapan, keterampilan, sikap, pengertian, harga diri, minat, watak, penyesuaian diri. Jadi bisa dikatakan bahwa belajar adalah sebagai suatu rangkaian kegiatan jiwa raga yang menuju kepada perkembangan pribadi manusia seutuhnya. Proses pembelajaran merupakan proses komunikasi, yaitu proses penyampaian pesan dari sumber pesan melalui saluran atau media tertentu ke penerima pesan.

\section{Efektivitas Model Example Non Example Dalam Pembelajaran Tajwid}

Beranjak dari pengamatan yang dilakukan penulis di TPQ Hikmatun Najah Blora, dengan menggunakan model example non example dalam pembelejaran Tajwid guru yang biasananya melaksanakan pembelajaran kurang efektif karena hanya berpusat kepada guru saja ataupun dalam menggunakan model pembelajarannya kurang mengenai bagian alat vital siswa sehingga pembelajaran terkesan membosankan karena ghirah atau semangat belajar siswa kurang terpacu berubah menjadi lebih efektif dan menyenangkan. Penggunaan media gambar berupa potongan ayat-ayat Al Qur'an yang ditunjukan oleh guru semakin menunjukan keefektifan proses pembelajaran tersebut terlihat semakin komunikatif, tepat sasaran dan tujuan dari materi pembelajaran Tajwid tercapai secara maksimal.

Sebagaimana menurut Cronbach dalam bukunya yang dikutip oleh Basuni Yusuf mengungkapkan bahwa dalam proses pembelajaran, seseorang berinteraksi langsung dengan objek belajar dengan menggunakan semua alat indranya. Jadi dapat ditarik sebuah benang merah bahwa secara umum pembelajaran yakni suatu kegiatan yang dilakukan oleh pendidik sehingga kognitif, afektif, dan psikomotorik peserta didik berubah ke arah yang lebih baik 16. Pembelajaran Tajwid yang dilakukan di TPQ Hikmataun Najah Blora dengan menggunakan model example non example pada dasarnya bertujuan untuk membantu peserta didik agar memperoleh berbagai pengalaman dalam kualitas membaca Al Qur'an sesuai dengan hukum tajwid yang baik dan benar ditandai

${ }^{16}$ Bistari Basuni Yusuf, "Konsep Dan Indikator Pembelajaran Efektif," Kajian Pembelajaran Dan Keilmuan, 2012. 32. 
sifatnya yang menekankan pada tidak hanya penguasaan pengetahuan saja tentang apa yang dipelajari, tetapi lebih menekankan pada internalisasi, tentang apa yang dipelajari sehingga tertanam dan berfungsi sebagai bekal dan ilmu serta dipraktekkan dalam membaca al Qur'an di kehidupan sehar-hari peserta didik. Hal ini membuktikan bahwa metode pembelajaran example non example sangat efektif digunakan dalam pemebalajarn tajwid khususnya di TPQ Hikmatun Najah dan tentu akan bisa diterapkan buat pembelajarn di tempat-tempat lain.

\section{Penutup}

Penggunakan model pembelajaran example non-example cukup efektif karena memungkinkan dapat mempengaruhi hasil belajar siswa karena siswa menjadi aktif karena memunculkan ghirah serta kekritisan berfikir para peserta didik sehingga memunculkan rasa keingintahuan yang tinggi terhadap materi yang disampaikan oleh pendidik terkait dengan pembelajaran tajwid. Pembelajaran yang efektif karena menggunakan seluruh indra untuk belajar. Peserta didik akan cepat faham materi dan menimbulkan rasa keingintahuan yang tinggi serta menimbulkan semangat belajar pula sehingga pembelajaran akan berhasil dan pastinya akan mempengaruhi hasil belajar siswa nantinya, pepatah mengatakan bahwa hasil tidak akan pernah menghianati sebuah proses, maka dari itu model example non-example maka sangat cocok diterapkan dalam materi pembelajaran tajwid oleh pendidik untuk menghasilkan output peserta didik yang ideal.

Saran dari penulis adalah, ketika mejadi seorang pendidik diharapkan selalu memberikan bilah bilah kesempatan kepada siswa untuk selalu aktif dalam pembelajaran. Karena untuk menghasilkan output yang sesuai dengan tujuan maka harus lebih intens untuk meningkatkan hasil belajar siswa dan semangat siswa serta keaktifan siswa terhadap materi pembelajaran apaun itu, seorang guru diharapkan dapat menggunakan berbagai model pembelajaran yang dapat disesuaikan dengan materi dan kondisi siswa, salah satunya adalah model pembelajaran Examples Non-Examples ini. Demikianlah ulasan dari penulis, jika didapati kesalahan tentu itu menjadi suatu kewajaran karena ada sebuah hadis yang menyatakan al insanu mahallul khoto' wan nisyan, manusia adalah tempatnya salah dan lupa. 


\section{Bibliografi}

Afandi, Muhamad. Model Dan Metode Pembelajaran Di Sekolah. Semarang, 2013.

Anggito, Albi, and Johan Setiawan. Metodologi Penelitian Kualitatif. Sukabumi, 2018.

Apriani. "Implementasi Model Pembelajaran Example Non Example." IKIP PGRI, 2010.

Darmadi. Pengembangan Model Dan Metode Pembelajaran Dalam Dinamika Belajar Siswa. Yogyakarta: CV.Budi Utama, 2017.

Djafar, Nur Asmah. "Penerapan Model Pembelajaran Example Non Example Untuk Meningkatkan Kemapuan Berfikir Kritis Peserta Didik Kelas VIII.K SMP Negeri 4 Sungguminasa Kabupaten Gowa." Kajian Dan Penelitian Biologi, 2014.

Habibah, Syarifah. "Penggunaan Model Pembelajaran Examples Non Examples Terhadap Ketuntasan Hasil Belajar Siswa Pada Materi Tokoh-Tokoh Pergerakan Nasional Kelas V SDN 70 Banda Aceh.” Pesona Dasar 3 (2016).

Johan, $A B$, and Fendi Lestiawan. "Penerapan Metode Pembelajaran Example Non Example Untuk Meningkatkan Keaktifan Dan Hasil Belajar DasarDasar Pemesinan." Taman Vokasi, 2018.

Kurniawan, Agung Rimba, and Diya Ul'hak. "Cara Guru Meningkatkan Keaktifan Siswa SD.” PGSD FKIP Universitas Jambi., 2017.

yansyah, and Eni Fariyatul Fahyuni. Inovasi Model Pembelajaran. Sidoarjo, 2016.

Rahman, Arif. Memahami Pendidikan Dan Ilmu Pendidikan. Yogyakarta: Leksbang Mediatama, 2008.

Rosalina, Selvia. "Penerapan Model Pembelajaran Example Non Example Untuk Meningkatkan Motivasi Dan Hasil Belajar Siswa Pada Mata Pelajaran PKn Kelas VIII B Di SMP Negeri 1 Kejayan Kabupaten Pasuruan. 2014. 
36 | Belajea: Jurnal Pendidikan Islam, Vol. 5, No. 01, 2020

Subadi, Tjipto. "Model Pembinaan Guru Ilmu Sosial Berbasis Lesson Study Menuju Pendidik Profesional.” Surakarta, 2018.

Timotius, Kris H. Pengantar Metodologi Penelitian: Pendekatan Manajemen Pengetabuan Untuk Perkembangan Pengetahuan. CV. Andi Offset. Yogyakarta, 2017.

Widayati, Ninik Sri, and Hafis Muaddab. Model-Model Pembelajaran Inovatif. El Haf Publishing. Jombang, 2012. .

Yusuf, Bistari Basuni. "Konsep Dan Indikator Pembelajaran Efektif." Kajian Pembelajaran Dan Keilmuan, 2012. 